Pendas : Jurnal IImiah Pendidikan Dasar, ISSN Cetak : 2477-2143 ISSN Online : 2548-6950 Volume III Nomor 2, Desember 2018

\title{
PENERAPAN MODEL QUANTUM WRITER UNTUK MENINGKATKAN \\ KETERAMPILAN MENULIS NARASI DI SEKOLAH DASAR (PTK DI KELAS V SEKOLAH DASAR CANGKUANG 01 KECAMATAN RANCAEKEK KABUPATEN BANDUNG)
}

\author{
Muh. Husen Arifin \\ Politeknik Al Islam Bandung \\ husenarifin2889@gmail.com
}

\begin{abstract}
Aims research for increasing the activity and learning ability of students in narrative writing skills. This research method is classroom action research. Students ability to learn to write the narrative in class $V$ in SD Negeri Cangkuang 01 with quantum writer model. Based on data obtained from result, the average value obtained that is in cycle I value obtained by learners equal to 67,52 , cycle II equal to 74,87 and in cycle III is equal to 77,70 . It was concluded that learning narrative writing with quantum writer model can improve the ability of students to narrative writing skills.
\end{abstract}

Keywords: quantum writer, narrative writing

\begin{abstract}
ABSTRAK
Penelitian dengan model quantum writer bertujuan untuk meningkatkan aktivitas dan kemampuan belajar peserta didik di dalam pembelajaran keterampilan menulis narasi pada pembelajaran Bahasa Indonesia. Metode penelitian ini adalah Penelitian Tindakan Kelas (PTK). Kemampuan belajar menulis narasi pada kelas $V$ di SD Negeri Cangkuang 01 dengan model quantum writer berdasarkan data yang diperoleh dari hasil belajar, nilai rata-rata yang diperoleh yaitu pada siklus I nilai yang diperoleh peserta didik sebesar 67,52 , siklus II sebesar 74,87 dan pada siklus III adalah sebesar 77,70. Disimpulkan bahwa pembelajaran menulis narasi dengan model quantum writer dapat meningkatkan kemampuan peserta didik terhadap keterampilan menulis narasi.
\end{abstract}

Kata Kunci: quantum writer, menulis narasi

\section{A. Pendahuluan \\ Keterampilan dalam berbahasa} memiliki kedudukan yang sangat penting terhadap pembelajaran bahasa Indonesia dan merupakan suatu kesatuan yang tak dapat dipisahkan. Sebab menulis merupakan kegiatan produktif dan ekspresif yang membutuhkan keterampilan khusus.

Kenyataan di lapangan dan penilitian lainnya pun menganggap bahwa keterampilan menulis di Indonesia masih jauh dengan harapan. Hal ini berdasarkan hasil penyimakan dari Suparno dan Yunus (2008) bahwa survei penelitian 
Pendas : Jurnal Ilmiah Pendidikan Dasar, ISSN Cetak : 2477-2143 ISSN Online : 2548-6950 Volume III Nomor 2, Desember 2018

terhadap guru bahasa Indonesia, yang umumnya responden menyatakan bahwa hal yang paling tidak disukai siswa dan guru adalah menulis atau mengarang. Selain itu menulis hanya dijadikan sekedar subjek saja dalam pengertian menulis dijadikan sebagai media yang tidak terlalu diperhatikan padahal keterampilan menulis dapat meningkatkan kecerdasan, mengembangkan daya inisiatif dan kreativitas, menumbuhkan keberanian, mendorong kemauan dan kemampuan dalam mengumpulkan informasi.

Pembelajaran menulis harus mendapatkan perhatian khusus dari berbagai instansi, khususnya Sekolah Dasar sebab dalam periode usia ini merupakan perkembangan penting dan fundamental bagi kesuksesan perkembangan selanjutnya.

Atas dasar tersebut, maka peneliti mengamati keterampilan menulis di Sekolah dasar salah satunya di Sekolah Dasar Negeri Cangkuang 01. Berdasarkan hasil pengamatan dan wawancara dengan guru sekait bahwa di Kelas V Sekolah Dasar Negeri Cangkuang 01 rata-rata siswa belum mampu menulis narasi. Umumnya mereka hanya mampu menulis pada paragraf pertama dan tak mampu menyelesaikannya. Adapun sebagian kecil lainnya, mereka hanya bisa menulis namun dalam pengorganisasiannya masih jauh dari ketuntasan minimal. Hal ini dapat disadari bahwa mereka belum mampu menyusun ide gagasan, dan mengembangkannya ke dalam bentuk karangan serta tidak tahu bagaimana cara menulis dan untuk apa mereka menulis sehingga ketuntasan belajar siswa masih rendah. Pengalaman belajar menulis yang dialami oleh siswa tersebut tidak terlepas dari kondisi gurunya sendiri, berdasarkan pengamatan peneliti terhadap guru sekait, umumnya hanya menugaskan siswa untuk menulis/mengarang dengan menugaskan secara klasikal tanpa pembaharuan pembelajaran serta tanpa memberikan tujuan jelas tentang kebermaknaan pembelajaran menulis. Sehingga siswa tidak tahu apa yang ingin ia tulis, tidak tahu bagaimana menyusun gagasan, dan tidak tahu bagaimana harus mengembangkan gagasan tersebut hal ini menyebabkan siswa takut akan menulis dan menyebabkan stres karena tidak tahu apa yang harus ia lakukan dengan gagasan tersebut. 
Pendas : Jurnal Ilmiah Pendidikan Dasar, ISSN Cetak : 2477-2143 ISSN Online : 2548-6950 Volume III Nomor 2, Desember 2018

Sehingga hal-hal tersebut dapat menurunkan motivasi dan minat siswa menurun sehingga aktivitas serta hasil belajar menurun. Hal ini yang menyebabkan mengapa nilai ketuntasan belajar rendah atau tidak optimal.

\section{B. Landasan Teori}

Menulis pada hakikatnya dianggap sebagai proses ataupun hasil. Menulis merupakan kegiatan yang dilakukan oleh seseorang untuk menghasilkan sebuah tulisan.

Berdasarkan hasil penyimakan dari Lian Gie (2002) bahwa menulis pada dasarnya merupakan suatu bentuk komunikasi (verbal) yang menggunakan simbol-simbol tulis sebagai mediumnya, yang semula ialah membuat huruf, angka, nama, dan sesuatu tanda kebahasaan apa pun dengan sesuatu alat tulis pada suatu halaman tertentu. Kini dalam pengertiannya luas menulis merupakan kata sepadan yang mempunyai arti yang sama seperti mengarang. Mengarang adalah segenap rangkaian kegiatan seseorang mengungungkapkan gagasan dan menyampaikannya melalui bahasa tulis mesyarakat pembaca untuk dipahami.
Labih lanjut menurut Semi (2007) bahwa "Menulis merupakan suatu proses kreatif memindahkan gagasan-gagasan ke dalam lambanglambang tulisan." Demi memindahkan gagasan-gagasan tersebut maka seseorang harus menguasai gagasan, unsur bahasa, gaya dan tata kebahasaan.

Berdasarkan hasil penyimakan dari Pusat Bahasa ( Syarif, dkk, 2009) bahwa paragraf narasi itu dimaksudkan untuk memberi tahu pembaca atau pendengar tentang apa yang telah diketahui atau apa yang dialami oleh penulisnya. Narasi lebih menekankan pada dimensi waktu dan adanya konflik. Didalam sebuah narasi harus memiliki tujuan. Tujuan tersebut menurut Semi (2007) bahwa "Menulis narasi bertujuan menceritakan kronologis peristiwa kehidupan manusia dalam artian menulis tersebut harus memiliki tujuan salah satunya bercerita mengenai kehidupan".

Berdasarkan kutipan dan penyimakan di atas dapat disimpulkan bahwa menulis narasi adalah suatu kegiatan seseorang yang mencurahkan isi, perasaan, dan gagasan berupa bahasa tulis yang didalam isinya menceritakan suatu 
Pendas : Jurnal Ilmiah Pendidikan Dasar, ISSN Cetak : 2477-2143 ISSN Online : 2548-6950 Volume III Nomor 2, Desember 2018

peristiwa secara kronologis yang didalamnya memuat konflik.

Dalam jenis-jenis tersebut ada daya pembeda lebih lanjut bahwa narasi sugestis memiliki ciri-ciri yaitu menyampaikan suatu makna atau amanat yang tersirat, menimbulkan daya khayal, penalaran hanya berfungsi sebagai alat untuk menyampaikan makna, sehingga kalau perlu penalaran dapat dilanggar, dan bahasanya lebih cenderung ke bahasa figuratif dengan menitikberatkan pada penggunaan kata-kata konotatif. Sedangkan narasi ekspositoris memiliki ciri memperluas pengetahuan, menyampaikan informasi faktual mengenai suatu kejadian, ceritanya berdasarkan pada penalaran untuk mencapai kesepakatan rasional dan dalam segi bahasanya lebih cenderung bahasa informatif dengan menitikberatkan pada penggunaan kata-kata denotatif dalam pengertian makna yang sebenarnya sama dengan makna lugas untuk menyampaikan sesuatu yang bersifat faktual.

Dalam menulis narasi hendaknya menyusun langkah-langah yang menekankan pada aspek apa yang ingin dikarang sehingga penulis memiliki tujuan jelas dalam menulis.
Dalam penceritaan ini penelit hendaknya mengedepankan amanat, dan merangkai peristiwa-peristiwa serta tokoh/ watak seperti apa yang ingin di tulis. Topik dalam menulis narasi ini harus berkesinambungan sehingga akhir ceritanya sesuai dengan topik tersebut.

Model quantum writer adalah model pembelajaran menulis yang menekankan pada aspek kreativitas dalam memulai ide gagasan, penguraian karangan, pengorganisasian dengan metode pembelajarannya yang menyenangkan.

Langkah-langkah dalam model quantum writer ini adalah memusatkan perhatian, pengaturan ide atau gagasan, memfokuskan ide dengan menguraikannya pada karangan, dan terakhir adalah pengoptilamal tulisan melaui revising. Lebih lanjut menurut De Porter (2010) yaitu menggunakan sistem PAK! Sebagai berikut:

$\mathrm{P}=$ PUSATKAN Pikiranmu; tuliskan beragam ide dan poin-poin utama.

$A=$ ATUR; atur poin-poin utamamu dalam peta Pikiran dan sebuah kerangka. 
Pendas : Jurnal Ilmiah Pendidikan Dasar,

$\mathrm{K}=\mathrm{KARANG}$; Fokus pada target penulisan dan buat draf karangan.

$$
! \quad=\text { HEBAT; Optimalkan }
$$

tulisanmu, buat menonjol.

\section{Metode Penelitian}

Fokus kegiatan meliputi pengamatan mengenai kemampuan intelektual subjek penelitian, serta sikap dan perilaku siswa dalam kegiatan pembelajaran dan mengidentifikasi permasalahan yang akan dijadikan penelitian, yaitu penerapan model quantum writer dalam meningkatkan keterampilan menulis narasi.

Subjek penelitian adalah siswa kelas V B yang terdiri dari 29 siswa yang terdiri atas 17 laki-laki dan 12 Perempuan. Dalam penelitian ini menggunakan teknik pengumpulan data observasi, catatan lapangan, tes, kuesioner, dan wawancara.

Standar kelulusan dalam
menulis narasi yaitu dengan menggunakan menggunakan standar kriteria ketuntasan minimal (KKM) membaca dalam pelajaran Bahasa Indonesia di kelas V SDN Cangkuang 01 dengan batas nilai minimal 60,00 $(60 \%)$.
Dan dalam menguji validitas hasil penelitian menggunakan teknik triangulasi.

\section{Hasil dan Pembahasan}

Demi melihat sejauhmana perkembangan menulis narasi dengan menerapkan model tersebut, maka sebagai peneliti sekaligus guru/pengajar, pembimbing, dan fasilitator membatasi siklus dengan tiga siklus yang tiap-tiap siklusnya mengambil dua tindakan.

Tabel 1 Temuan Esensial Proses Pembelajaran Siklus I Tindakan 1

\begin{tabular}{|c|c|}
\hline Tahapan & Temuan \\
\hline $\begin{array}{c}\text { Kegiatan } \\
\text { Awal }\end{array}$ & $\begin{array}{l}\text { Siswa nampak lelah dan } \\
\text { tidak bersemangat hal ini } \\
\text { dapat disadari sebab } \\
\text { sebelumnya siswa telah } \\
\text { melakukan ujian tengah } \\
\text { semester selain itu } \\
\text { suasana yang } \\
\text { menjelang sore } \\
\text { mempengaruhi terhadap } \\
\text { keminatan belajar. }\end{array}$ \\
\hline $\begin{array}{l}\text { Kegiatan Inti } \\
\text { Pemusatan } \\
\text { pikiran } \\
\text { Atur pikiran }\end{array}$ & $\begin{array}{lr}\text { Ada dua siswa yang } \\
\text { melakukan keributan } \\
\text { sehingga membuat } \\
\text { siswa lain tidak } \\
\text { konsentrasi dan gaduh. }\end{array}$ \\
\hline $\begin{array}{c}\text { Kegiatan } \\
\text { Akhir }\end{array}$ & $\begin{array}{l}\text { Pada kegiatan akhir ini } \\
\text { tidak ada catatan } \\
\text { penting. } \\
\text { Semua terkendali sesuai } \\
\text { dengan rencana yang } \\
\text { diharapkan. }\end{array}$ \\
\hline
\end{tabular}

Temuan Esensial Proses Pembelajaran Siklus I Tindakan 2

\begin{tabular}{|c|l|}
\hline Tahapan & \multicolumn{2}{|c|}{ Temuan } \\
\hline & Siswa nampak lelah dan \\
Kegiatan & tidak bersemangat hal ini \\
Awal & dapat disadari sebab \\
& sebelumnya siswa telah \\
& melakukan ujian tengah \\
& semester selain itu suasana \\
\hline
\end{tabular}


Pendas : Jurnal IImiah Pendidikan Dasar, ISSN Cetak : 2477-2143 ISSN Online : 2548-6950 Volume III Nomor 2, Desember 2018

\begin{tabular}{|c|c|}
\hline & $\begin{array}{l}\text { yang menjelang sore } \\
\text { mempengaruhi terhadap } \\
\text { keminatan belajar. }\end{array}$ \\
\hline $\begin{array}{l}\text { Kegiatan Inti } \\
\text { - } \text { Karang } \\
\text { - } \text { Pengoptim } \\
\text { alan } \\
\text { Tulisan }\end{array}$ & $\begin{array}{l}\text { Ketika mengarang tidak ada } \\
\text { catatan penting, hanya saja } \\
\text { ketika dalam } \\
\text { mengoptimalkan tulisan } \\
\text { kebingungan dan waktu } \\
\text { yang sempit sehingga siswa } \\
\text { terburu-buru dan membaca } \\
\text { hanya sekilas. }\end{array}$ \\
\hline $\begin{array}{l}\text { Kegiatan } \\
\text { Akhir }\end{array}$ & $\begin{array}{l}\text { Ada tiga siswa yang tidak } \\
\text { dapat mengoptimalkan } \\
\text { tulisan disebabkan waktu } \\
\text { yang terbatas serta daya } \\
\text { konsentrasi yang sedikit } \\
\text { menurun. }\end{array}$ \\
\hline
\end{tabular}

Pada siklus I, $22 \%$ atau sebanyak 9 siswa masih belum mampu membedakan menulis narasi dengan deskripsi. Aktivitas pembelajaran dilanjutkan dengan tanya jawab mengenai stategi gugus, peta pikiran dan kerangka karangan.

Temuan Esensial Proses Pembelajaran Siklus II Tindakan 1

\begin{tabular}{|c|l|}
\hline Tahapan & \multicolumn{1}{|c|}{ Temuan } \\
\hline \multirow{5}{*}{ Kegiatan } & $\begin{array}{l}\text { Siswa nampak lelah dan } \\
\text { menurun motivasinya } \\
\text { dikarenakan pada jam 7.00- } \\
7.30 \text { siswa melakukan senam } \\
\text { pagi, namun setelah guru } \\
\text { memberikan permainan }\end{array}$ \\
$\begin{array}{l}\text { "tangkap jari teman, } \\
\text { bebaskan jari kita. Motivasi }\end{array}$ & $\begin{array}{l}\text { serta konsentrasinya muncul. } \\
\text { Dan siswa semangat dalam } \\
\text { mengikuti pembelajaran }\end{array}$ \\
\hline Kegiatan Inti & $\begin{array}{l}\text { Proses pembelajaran } \\
\text { berlangsung dengan lancar, } \\
\text { dan ketika guru melakukan } \\
\text { tanya jawab sebagian besar } \\
\text { siswa menjawab dalam artian } \\
\text { keberaniannya } \\
\text { muncul. sudah } \\
\text { Pada saat guru melengkapi } \\
\text { media dengan memberikan } \\
\text { musik klasik pada saat siswa } \\
\text { mengerjakan lembar kerja } \\
\text { siswa, musik tersebut tiak } \\
\text { terlalu jelas terdengar siswa }\end{array}$ \\
\hline
\end{tabular}

yang duduk di belakang, serta pada iti pembelajaran ini ada tiga siswa yang kehilangan konsentrasi atau tidak bergairah sehingga melakukan aktivitas sendiri.

\begin{tabular}{|c|l|}
\hline & melakukan aktivitas sendiri. \\
\hline $\begin{array}{c}\text { Kegiatan } \\
\text { Akhir }\end{array}$ & $\begin{array}{l}\text { Pada akhir pembelajaran } \\
\text { tidak ada catatan penting. }\end{array}$ \\
\hline
\end{tabular}

Temuan Esensial Proses Pembelajaran Siklus II Tindakan 2

\begin{tabular}{|c|c|}
\hline Tahapan & Temuan \\
\hline $\begin{array}{c}\text { Kegiatan } \\
\text { Awal }\end{array}$ & $\begin{array}{l}\text { Penelitian dilaksanakan pada } \\
\text { jam pagi awal pembelajaran } \\
7.00-8.10 \text { sehingga siswa } \\
\text { masih semangat namun } \\
\text { konsentrasi mereka belum } \\
100 \% \text { Sehingga guru } \\
\text { mengadakan permainan } \\
\text { sederhana pada saat guru } \\
\text { melakukan permainan } \\
\text { sederhana, beberapa siswa } \\
\text { masih belum terkonsentrasi. } \\
\text { Umumnya mereka terkecoh } \\
\text { pada intonasi juga lafal guru. }\end{array}$ \\
\hline Kegiatan Inti & $\begin{array}{l}\text { Proses pembelajaran } \\
\text { berlangsung dengan lancar, } \\
\text { dan ketika guru melakukan } \\
\text { tanya jawab sebagian besar } \\
\text { siswa menjawab dalam artian } \\
\text { keberaniannya sudah } \\
\text { muncul. } \\
\text { Pada saat guru melengkapi } \\
\text { media dengan memberikan } \\
\text { musik klasik pada saat siswa } \\
\text { mengerjakan lembar kerja } \\
\text { siswa, musik tersebut tiak } \\
\text { terlalu jelas terdengar siswa } \\
\text { yang duduk di belakang, serta } \\
\text { pada iti pembelajaran ini ada } \\
\text { tiga siswa yang kehilangan } \\
\text { konsentrasi/ melamun. }\end{array}$ \\
\hline $\begin{array}{c}\text { Kegiatan } \\
\text { Akhir }\end{array}$ & $\begin{array}{l}\text { Disebabkan ketiga siswa } \\
\text { tersebut kehilangan } \\
\text { konsentrasi, sehingga } \\
\text { mempengaruhi kinerja dalam } \\
\text { mengerjakan lembar kerja } \\
\text { siswa. Sehingga guru } \\
\text { memberikan khusus } \\
\text { penambahan waktu pada } \\
\text { ketiga siswa tersebut. Ketiga } \\
\text { siswa tersebut. }\end{array}$ \\
\hline
\end{tabular}

Berdasarkan analisis dan refleksi dari siklus II mengenai menulis 
Pendas : Jurnal Ilmiah Pendidikan Dasar, ISSN Cetak : 2477-2143 ISSN Online : 2548-6950 Volume III Nomor 2, Desember 2018

narasi dengan menerapkan model quantum writer maka guru akan memfokuskan pada pembelajaran ciriciri menulis narasi dan langkahlangkah model quantum writer khususnya pada pemusatan pikiran, kerangka karangan, draf karangan, dan pengoptimalan tulisan yang menekankan pada pemprosesan draf dan ejaan.

Temuan Esensial Proses Pembelajaran Siklus III Tindakan 1

\begin{tabular}{|c|c|}
\hline Tahapan & Temuan \\
\hline $\begin{array}{l}\text { Kegiatan } \\
\text { Awal }\end{array}$ & $\begin{array}{lr}\text { Guru memberikan yel-yel } \\
\text { serta } & \text { permainan } \\
\text { sederhana } & \text { guna } \\
\text { meningkatkan } & \text { motivasi } \\
\text { juga pemokusan perhatian } & \\
\text { siswa. }\end{array}$ \\
\hline Kegiatan Inti & $\begin{array}{l}\text { Proses pembelajaran } \\
\text { berlangsung dengan } \\
\text { lancar, dan ketika guru } \\
\text { melakukan tanya jawab } \\
\text { sebagian besar siswa } \\
\text { menjawab dalam artian } \\
\text { keberaniannya } \\
\text { muncul. } \\
\text { Pada sudah } \\
\text { melengkapi media dengan } \\
\text { memberikan musik ceria/ } \\
\text { instrumen inspirational } \\
\text { moment pada saat siswa } \\
\text { mengerjakan lembar kerja } \\
\text { siswa dan siswa nampak } \\
\text { menikmati musik tersebut. }\end{array}$ \\
\hline $\begin{array}{l}\text { Kegiatan } \\
\text { Akhir }\end{array}$ & $\begin{array}{l}\text { Pada akhir pembelajaran } \\
\text { tidak ada catatan penting. }\end{array}$ \\
\hline
\end{tabular}

Dari temuan esensial yang dipaparkan di atas, maka menunjukkan bahwa semangat belajar siswa mulai muncul ketika guru memusatkan perhatian dengan melakukan permainan sederhana. Pada saat inti pembelajaran guru menjelaskan kekurangan dari proses pembelajaran pada siklus kedua dilengkapi dengan media musik dan gambar. Saat guru menugaskan siswa untuk mengisi lembar kerja, siswa nampak senang.

\section{Berdasarkan}

penjabaran kemampuan tersebut hasil belajar adanya peningkatan dan dikatakan tuntas dalam menulis narasi sebab berada di atas rata-rata kriteria ketuntasan minimal (KKM) menulis dalam pelajaran Bahasa Indonesia di kelas V SDN Cangkuang 01.

Aktivitas siswa dalam menulis narasi dengan menerapkan model quantum writer terjadi peningkatan. Siklus I rata-rata nilai aktivitas siswa adalah 63,21\%, siklus II adalah $73,68 \%$ terjadi peningkatan 10,47\% dan pada siklus III terjadi peningkatan $12,09 \%$.

Hal ini membuktikan bahwa adanya keberhasilan dalam proses pembelajaran ditunjang dengan hasil pengumpulan observer dan hasil kuesioner yang rata-rata menyatakan bahwa pembelajaran dengan model quantum writer sangat menyenangkan. Aktivitas tersebut akan mempengaruhi terhadap kemampuan siswa dalam menulis narasi. 
Pendas : Jurnal Ilmiah Pendidikan Dasar, ISSN Cetak : 2477-2143 ISSN Online : 2548-6950 Volume III Nomor 2, Desember 2018

Kemampuan siswa dalam siklus I rata-rata nilainya dalam persentase (\%) bernilai $67,52 \%$ terjadi peningkatan $7,35 \%$ menjadi $74,, 87 \%$ pada siklus II, dan pada siklus III terjadi peningkatan $2,83 \%$ menjadi $77,70 \%$.

Adapun kekurangan dalam pembelajaran siklus I ini disebabkan adanya kekurangan dari penulis yang bertindak sebagai guru belum mengoptimalkan keterampilan dalam menjelaskan, variasi, serta pengelolaan kelas dan pengoptimalan media pembelajaran.

Rekomendasi selanjutnya adalah pengoptimalan media, guru harus mempersiapkan sound/ active speaker yang disesuaikan dengan ruangan kelas supaya media tersebut dapat memfokuskan perhatian siswa dalam menyebarkan ide gagasannya. Sehingga tidak ada keluhan dari beberapa siswa tentang ketidakjelasan suara yang tidak sampai atau tidak terlalu jelas/ terdengar pada jajaran bangku belakang.

Grafik 1 Nilai Rata-rata Aktivitas Siswa dalam Menulis Narasi di Kelas V Sekolah Dasar
Secara garis besar gambar tersebut menunjukan, bahwa aktivitas siswa dalam menulis narasi dengan menerapkan model quantum writer terjadi peningkatan. Siklus I rata-rata nilai aktivitas siswa adalah $63,21 \%$, siklus II adalah $73,68 \%$ terjadi peningkatan $10,47 \%$ dan pada siklus III terjadi peningkatan 12,09\%.

Aktivitas pembelajaran dalam rangka meningkatkan hasil belajar dalam menulis narasi pada pembelajaran Bahasa Indonesia dalam penelitian ini, telah disesuaikan dengan tahap-tahapan pembelajaran dengan menggunakan model quantum writer. Tahapan tersebut menurut Deporter (2010) adalah "Pemusatan pikiran, pengaturan pikiran, karang dan pengoptimalan tulisan".

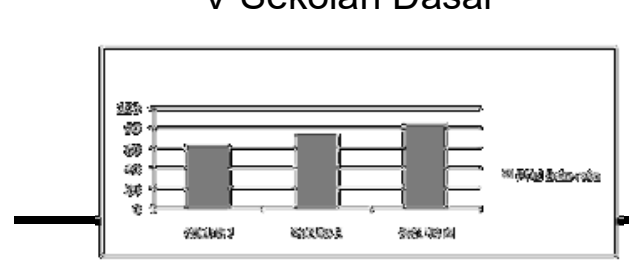


Pendas : Jurnal IImiah Pendidikan Dasar, ISSN Cetak : 2477-2143 ISSN Online : 2548-6950 Volume III Nomor 2, Desember 2018

Grafik 1 Nilai Rata-rata Kemampuan Siswa dalam Menulis Narasi di Kelas V Sekolah Dasar

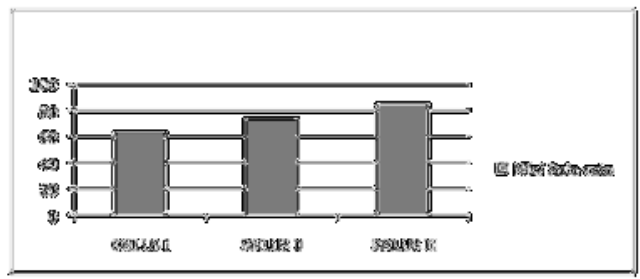

Gambar tersebut menunjukan bahwa kemampuan siswa dalam menulis narasi terjadi peningkatan. Kemampuan siswa dalam siklus I ratarata nilainya dalam persentase (\%) bernilai $67,52 \%$ terjadi peningkatan $7,35 \%$ menjadi $74,, 87 \%$ pada siklus II, dan pada siklus III terjadi peningkatan $2,83 \%$ menjadi $77,70 \%$. Berdasarkan gambaran tersebut maka maka tiap siklusnya meningkat terhadap kemampuan siswa dalam menulis narasi.

Berdasarkan hasil aktivitas mengenai proses pembelajaran dan hasil kemampuan belajar siswa dalam menulis narasi dengan menerapkan model quantum writer pada penelitian ini, menunjukkan bahwa pembelajaran menulis narasi dengan menerapkan model quantum writer dapat meningkatkan aktivitas belajar dan kemampuan belajar siswa dalam menulis narasi.

\section{E. Kesimpulan}

Penerapan model quantum writer dalam pembelajaran menulis narasi ini dapat meningkatkan kemampuan siswa sehingga terampil dalam menulis khususnya pada menulis narasi. Ditunjukan oleh penilaian kemampuan siswa yang menunjukan peningkatan dari siklus I sampai siklus III.

Adapun nilai rata-rata yang diperoleh setiap siklusnya, yaitu pada siklus I nilai yang diperoleh siswa sebesar $67,52 \%$, siklus II sebesar $74,87 \%$ dan pada siklus III adalah sebesar $77,70 \%$ yang sesuai dengan KKM SDN Cangkuang 01 dengan batas nilai 60,00 dan dikatakan dapat menuntaskan.

Dengan demikian, maka pembelajaran menulis narasi di kelas V SD dengan penerapan model quantum writer dapat meningkatkan kemampuan menulis narasi.

\section{DAFTAR PUSTAKA}

Abidin, Y. (2010). Guru dan Pembelajaran Bermutu. Bandung: Rizqi Press.

Abidin, Y. (2010). Prosa Fiksi. Tasikmalaya: HZAA Press.

Deporter, B. (2009). Quantum Writer. Bandung: Kaifa. 
Gie, T. (2002). Terampil Mengarang. Yogyakarta: Andi Offset.

Haryadi, \& Zamzami. (1996).

Peningkatan Keterampilan Berbahasa Indonesia.

Yogyakarta: Depdikbud.

Iskandar, W., \& Sunendar, D. (2009).

Strategi Pembelajaran Bahasa

Bandung: Remaja

Rosdakarya.

Kurniawan, E., \& Mutaqimah , E. (2009). Penilaian. Jakarta: Depdiknas.

Marno, \& Idris. (2008). Strategi dan Metode Pengajaran. Jakarta: Arruz Media.

Nurgiyantoro, B. (2010). Penilaian Pembelajaran Bahasa. Yogyakarta: BPFE.

Purwanto . (1997). Metodologi Pengajaran Bahasa Indonesia. Jakarta: Rosda Jaya Putra.

Resmini, \& dkk. (2006). Pembinaan dan Pengembangan

Pembelajaran Bahasa dan Sastra Indonesia. Bandung: UPI Press.

Santosa. (2007). Materi Pembelajaran Bahasa Indonesia SD. Jakarta: Universitas Terbuka.

Semi , A. (2007). Dasar-dasar Keterampilan Menulis. Bandung: Angkasa.

Syarif, Zulkarnaini, \& Sumarno. (2009). Menulis. Jakarta: Depdiknas.

Tarigan. (1994). Menulis Sebagai Suatu Keterampilan Berbahasa. Bandung: Angkasa.

Yunus. (2009). Menulis. Jakarta: Universitas Terbuka. 